\title{
Anti-Phosholipid Syndrome Misdiagnosed As Multiple Sclerosis: A Case Report.
}

\author{
Multipl Skleroz Olarak Yanlı̧ Teşhis Edilen Antifosfolipid Sendromu: Bir Olgu Sunumu.
}

Eskisehir Osmangazi University Department of Neurology, Eskisehir, Turkey

Correspondence:

Gülnur TEKGÖL UZUNER

Eskisehir Osmangazi University,

Department of Neurology, Eskisehir,

Turkey

e-mail: gulnurt@ogu.edu.tr

\section{Gulnur Tekgol Uzuner, Atilla Ozcan Ozdemir, Cengiz Korkmaz, Nevzat Uzuner}

\section{Abstract}

Multiple sclerosis (MS) and anti-phospholipid syndrome (APS) are chronic, immune-mediated, relapsing-remitting disorders affecting young adults. APS is characterized by thrombosis and pregnancy mortality associated with anti-phospholipid antibodies. The diagnosis of APS may be difficult, and it is not uncommon for patients with APS to be misdiagnosed with multiple sclerosis. In this case report, we describe a patient who was diagnosed as having multiple sclerosis for eleven-year. Initially, the patient had neurological deficits with relapsing-remitting courses, like MS but he had not classic magnetic resonance imaging appearance of MS and absence of oligoclonal bands in the cerebrospinal fluid. He did not meet the 'dissemination criteria in time and place' specified in the MS diagnostic criteria. Also, he had an acute myocardial infarction and ischemic stroke at different times. The diagnosis of primary APS was made after the patient had thrombotic attacks, seizure and was positive for anti-phospholipid antibodies (aPLs) twice. Our observations raise awareness about the importance of the early and correct diagnosis of APS. When assessing MS patients, clinicians should consider APS, if the MS has atypical features.

Keywords: Multiple sclerosis; Anti-phospholipid syndrome; misdiagnose; multiple sclerosis-like syndrome.

\section{Özet}

Multipl skleroz ve anti-fosfolipid sendromu (AFAS), genç yetişkinleri etkileyen kronik, immün aracıll, relapsing-remitting bozukluklardır. AFAS, anti-fosfolipid antikorları ile ilişkili tromboz ve gebelik mortalitesi ile karakterizedir. AFAS tanısı zor olabilir ve AFAS’lı hastaların yanlıs multipl skleroz tanısı alması nadir değildir. Bu olgu sunumunda, on bir yıldır multipl skleroz tanısı ile izlenen bir hastayı tanımladık. Başlangıçta hastanın MS benzeri relapsing- remitting seyirli nörolojik defisitleri vardı ancak MS'in klasik manyetik rezonans görüntüleme görünümü ve beyin omurilik sıvısında oligoklonal bantlar yoktu. Hasta MS tanı kriterlerinde belirtilen 'zamanda ve mekanda yayılım kriterleri' ni karşılamıyordu. Ayrıca farklı zamanlarda akut miyokard infarktüsü ve iskemik inme geçirmişti. Primer AFAS tanısı, hastanın iskemik serebral inme geçirmesi, nöbet ve iki kez aPL pozitif olması üzerine konuldu. Gözlemlerimiz, AFAS’’n erken ve doğru teşhisinin önemi konusunda farkındalık yaratmaktadır. MS hastalarını değerlendirirken, klinisyenler MS'nin atipik özellikleri varsa AFAS’’ düşünmelidir.

Anahtar Kelimeler: Multipl skleroz; Antifosfolipid sendrom; yanlış tanı; multipl skleroz benzeri sendrom

Received 04.08.2021 Accepted 10.01.2022 Online published 11.01.2022 


\section{Introduction}

Anti-phospholipid antibody (Hughes) syndrome (APS) is an autoimmune disorder which is characterized by thrombosis and pregnancy mortality associated with antiphospholipid antibody including persistent lupus antibody, anti-beta 2 glycoprotein I and anti- cardiolipin antibody. (1). The incidence of APS has not known certainly but approximately 5 in 100.000 per year and prevalence is 40-50 in 100000 per year (2).

Anti-phospholipid syndrome is especially associated with other autoimmune disorder, especially systemic lupus erythematosus, and may occur as primary and secondary depending on the underlying systemic disease. Rarely, it may accompany infections, malignancy, and drugs.

Association of multiple sclerosis (MS) with clinical syndromes resembling a mainly relapsing remitting pattern has been reported, such as many connective tissue diseases, especially APS, SLE and Sjogren's syndrome. APS is included in the differential diagnosis of multiple sclerosis. Neurological symptoms can be onset characteristics or occur during disease course. Apart from recurrent vascular lesions, they can be seen symptoms affecting central nerve system such as transverse myelitis resembling multiple sclerosis, and white matter lesions. The pathological process underlying the neurological symptoms is not known exactly. These symptoms are presumed to occur by immune-mediated mechanisms secondary to ischemic processes involving brain tissue or to the direct effects of antiphospholipid antibodies on neuronal tissue (3).

Although diagnostic criteria of MS have been significantly improved since half a century, diagnosis of MS is continuing to base on clinical and radiologic findings with limited specificity. It has been pointed that diagnosis should be done in case of "no better explaining than MS" in updated every diagnostic criterion. Today, recognising of MS-like diseases and syndromes improved even so misdiagnosis of MS is continuing to be important problem (4).
In this case report, we aimed to evaluate diagnostic difficulties and treatment modalities in a patient with APS who had an initially misdiagnosis of multiple sclerosis.

\section{Case}

A 39-year-old male patient, first he has admitted to other hospital with blurred vision, paraesthesia, and weaknesses of left side of the body in 2009. It could not be reached any results of laboratory and magnetic resonance imaging (MRI) except oligoclonal band type 1 negativity. Interferon beta 1a 3 times a week treatment has been started at the same neurology clinic but he did not use it. We learned from the patient that he had five attacks in the subsequently 5- year and was given high dose methylprednisolone intravenously at each attack and recovered without any disability. All attacks of patients were same form each other like paraesthesia of left side of the body, imbalance, and blurred vision. He started using interferon beta 1a subcutaneously from 2014 .

In 2017, 2018, and 2019, he was suffered from 3 times acute myocardial infarction, and underwent coronary stenting. Acetylsalicylic acid treatment was started. Anticoagulation is recommended in recurrent thrombosis events secondary to AFAS. Since our case was probably not diagnosed with AFAS at that time, we think that antiaggregant therapy may have been given only.

In 2019, he had his seventh attack and presented with left sided lower extremity weaknesses, however he did not benefit form steroid therapy.

In May of 2020, he referred to the emergency clinic of our hospital with sudden onset right sided hemiplegia. CT angiography revealed chronic occlusion of internal carotid artery on the cerebral tomography, and diffusion restriction at the corona radiata and posterior internal capsule on the diffusion sequence of MRI (Figure 1). Cerebral MRI revealed hyperintense lesions adjacent to the pons and bilateral ventricles (Figure 2A and 2B). $\mathrm{He}$ was diagnosed as acute ischaemic stroke and received intravenous thrombolytic therapy in 
our stroke unit. After this treatment, his neurological examination was normal except previously mild left lower extremity paralysis. After few days doing digital subtraction angiography (DSA) was performed demonstrated right internal carotid artery occlusion. Right sided MCA was filled with collateral via anterior communicating artery. Additionally, irregularity of vessels in both MCA territory including M3, M4 vessels were observed (Figure 3). According to laboratory results, infection markers was negative, and coagulation markers and homocysteine were normal. Anti-nuclear antibody, anti- dsDNA, ENA panel and anti- cardiolipin IgM and IgG were negative. Also, LA1/LA2 rate 1.23 and lupus anticoagulant were positive at low titre. The patient was consulted to the rheumatology department. When evaluating with clinical findings, lupus anticoagulant positivity in low titre, absence of livedo reticularis they did not find strong evidence in terms of any rheumatologic vasculitis syndrome affecting CNS. We discharged to the patient under antiaggregant therapy.

In March of 2021, he presented to our clinic complaining about recurrent loss of consciousness. He had symptoms like seizures such as sudden loss of consciousness and contraction throughout the body. Electroencephalography was normal. But antiepileptic treatment was given. In the laboratory results, LA1/LA2 rate was positive at middle titres in this time, the activity of protein $\mathrm{C}$ was low, and levels of the complement $\mathrm{C} 3$ and $\mathrm{C} 4$ were high. The patient was consulted to the rheumatology department again. Because of multiple thrombotic attacks and persistent lupus anticoagulant positivity, he was diagnosed as primary APS. Coumadin was added to his previous acetylsalicylic acid treatment and hydroxychloroquine 1x $200 \mathrm{mg}$ was started. The patient's follow-up and treatment continue in the rheumatology and neurology stroke clinic with the diagnosis of primary APS.

\section{Discussion}

In this report, we present a patient with primary APS who was misdiagnosed and treated for MS.

The anti-phospholipid syndrome is a systemic autoimmune disorder characterized by recurrent thrombosis and/or obstetrical morbidity along with persistent antiphospholipid antibodies (APLA), including lupus anticoagulant (LA), anti- $\beta 2-$

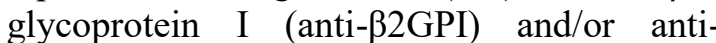
cardiolipin (aCL) antibodies (1).

According to Sydney revision, classification of APS requires at least one clinical manifestation of vascular thrombosis or obstetrical events and the presence of at least two positive laboratory criteria $\mathrm{aCL}$ IgG or IgM and/or a 32 GPI IgG or IgM at moderate titres and/or LA positivity) on two separate occasions at least 12 weeks apart (1).

Thromboses are one of the hallmarks of this syndrome, and venous thrombosis, or embolism, is the most frequent manifestation. However, by contrast with thromboses associated with congenital thrombophilia's, those associated with APS might also occur in any vascular bed. In the arterial bed, the CNS is most generally affected (5), usually in the form of stroke or transient ischaemic attacks. Antiphospholipid antibodies have also been associated with venous sinus thrombosis, myelopathy, chorea, migraine, and epilepsy (6). And, antiphospholipid antibodies are associated with cardiac valvular disease, with the mitral valve most frequently affected, followed by the aortic valve. Regurgitation is more common than is stenosis and many patients remain asymptomatic for years (7). Acute coronary syndromes are much less prevalent than cerebrovascular disease (5). Antiphospholipid syndrome nephropathy, livedo reticularis, haemolytic anaemia, retinal artery or vein thrombosis, amaurosis fugax, pulmonary hypertension, leg ulcers, digital gangrene, osteonecrosis, adrenal haemorrhage and Budd- Chiari syndrome are in other unusual or rare clinical manifestations of APS (8). 
The original description from APS included cerebrovascular disease and myelitis as APS neurological manifestations (9). Thereafter, a wide spectrum of manifestations was described and more recently APS neurological manifestations were classified as thrombotic and non-thrombotic (10). Central nervous system (CNS) thrombotic manifestations include stroke, transient ischemic attack (TIA), and cerebral venous thrombosis (CVT). CNS non-thrombotic manifestations include cognitive dysfunction (CD), migraine, seizure, multiple MS-like syndrome, transverse myelitis (TM), movement disorders, and psychiatric symptoms. $(11,12$, 13).

Multiple sclerosis-like syndrome, also called lupoid sclerosis, was described as a rare neurologic manifestation of primary APS (14). Patients may present unbalance, visual or sensory complaints and other neurological deficits with relapsing-remitting course, like MS (15). Furthermore, APS patients may present brain MRI with T2 hyperintense brain lesions, which may not be easily differentiated from MS. It may be particularly misleading, as scattered hyperintense subcortical white matter lesions are the most common MRI finding in APS (16).

Diagnostic criteria, as well as the role of antinuclear antibodies (ANA) and aPL are still matter of debate (17). Several studies evaluated aPL in definite MS patients and in MS-like patients; however, their relevance are still unknown due high variability findings and methodological limitations. Prevalence of $\mathrm{aCL}$ of $6 \%$ for the IgG isotype and between $2 \%$ and $69 \%$ for the IgM isotype in MS patients have been described $(18,19)$. Although aPL frequency was higher in MS patients with exacerbations, the significance of this autoantibody titre elevation is still not fully understood (20). In studies, the incidence of aCL in patients with MS was found to be between $6 \%$ and $28 \%(21,22)$. There was no significant difference in clinical characteristics of MS when comparing aCLpositive and -negative MS patients (23). It was found that $2 \%$ to $28 \%$ of MS patients had positive anti-b2GPI antibodies compared with controls; both aCL and anti-b2GPI were of the IgM type $(24,25)$. Few studies are available with lupus anticoagulant, and in a study by Garg et al., they found lupus anticoagulant positive in only 1 of 78 MS patients (25). There is a need for studies on the relationship between MS and anti-phospholipid antibodies. MS is an immune-mediated neuroinflammatory and neurodegenerative disease of the CNS. For diagnosis, dissemination of the disease process both in space and time should be demonstrated within the CNS by clinical and neuroimaging findings. Dissemination in space (DIS) should be verified either by neuroimaging (MRI) or by clinical findings demonstrating multifocal involvement of the CNS at the designated sites. The criteria for dissemination in time (DIT) needs to be satisfied clinically either by the presence of recurrent attacks or a steady progression and/or by neuroimaging showing asymptomatic enhancing lesions on the initial scan or the appearance of new lesions on follow-up scans. In individuals reporting symptoms and signs suggestive of MS, inflammatory-demyelinating lesions suggestive of MS spreading across time and space should be demonstrated with MRI. For DIS requires at least $1 \mathrm{~T} 2$ lesion in 2 regions of the 4 CNS areas, which are juxtacortical (lesions must contact cortex), periventricular (lesions must contact ventricles), infratentorial, and spinal cord. To perform DIT, the presence of 1 or more contrastenhancing lesions on the initial MRI or the development of any new T2 lesions or oligoclonal band positivity on the follow-up MRI is required. It is also essential to study the cerebrospinal fluid (CSF) in people who are suspected to have MS, even when the neurologist is comfortable with the diagnosis. However, the CSF is not only important in supporting the diagnosis, but at times it may reveal unexpected findings, such as a high level of protein, a low glucose level, or an elevated number of cells. In case of a negative oligoclonal band, the result is less likely to be MS and it should be made a well differential diagnosis. Finally, there should be no better explanation to account for symptoms and signs or MRI findings (26).

In our case was diagnosed with MS in the hospital at the neurology clinic where he applied. Since this patient did not present to our hospital at the beginning of his symptoms, 
we don't know how MS diagnosis has been established. MS diagnosis was being made using McDonald criteria in clinical practice. According to Mc Donald criteria, for diagnose of MS, if the patient has one clinic attack related demyelinating disease needed to find demyelinating lesions associated with MS in MRI and oligoclonal band positivity (27). Because we couldn't reach previously MRIs of this patient, it is impossible that criticize whether how the diagnosis was made but oligoclonal band negativity in the patient poses a question mark for the definitive diagnosis of MS. Therefore, a detailed differential diagnosis should have been made before a definitive MS diagnosis was made in our case. We think that differential diagnosis was not considered in this patient at the beginning and during the follow-up.

In case of clinical findings atypical for MS, such as acute stroke-like symptoms, clinical stereotype (attacks always originate from the same central nervous system region), and seizures other diseases other than MS should be investigated. In our case, the attacks generally included similar findings. In addition, the fact that the patient had AMI 3 times at younger age and was admitted to us with acute stroke at the last time, and the addition of epileptic seizures in the follow-up, caused us to approach the diagnosis of MS with suspicion. In the MRI of the patient, taken when he applied to us for ischemic stroke, we found that besides the finding of acute infarction, other lesions were generally located in the subcortical, thalamic, periventricular (not juxta-ventricular) and pons. No juxtacortical lesion was detected. Lesions in the pons were mostly centrally located lesions compatible with ischemia. The patient's MR images included findings suggestive of ischemic vascular disease rather than MS. No lesion was observed in the spinal cord MRI of the patient. Moreover, findings consistent with vasculitis were found in the patient's DSA. These findings take us away from the diagnosis of MS. We have already detected pathology in APS-related tests in laboratory tests. When we evaluated it together with the rheumatology department, we decided that the patient had primary APS with all findings.
Despite significant improvements today, diagnostic criteria for MS continue to be based on symptoms, signs, paraclinical tests and radiological findings of limited specificity. Although recognition of diseases and syndromes that may mimic MS has improved, the misdiagnosis of MS remains an important problem. Hughes et al. retrospectively reviewed 27 patients previously diagnosed with MS by a neurologist. All 27 patients had been referred to their lupus clinic because of symptoms suggesting an underlying connective tissue disease, uncommon findings for MS on magnetic resonance imaging, atypical evolution of MS, or antiphospholipid antibody positivity. In the past medical history, 8 patients with primary APS and 6 with systemic lupus erythematosus had had symptoms related to these conditions. They found that either neurologic symptom and physical examination of the patients were not different from those common in MS patients, and laboratory findings were not helpful enough in distinguishing between APS and MS. According to MR findings, MS patients had more lesions in the white matter, cerebellum, and pons, whereas APS patients had more lesions in the putamen. They concluded that MRI alone is not sufficient to differentiate APS from MS (28).

In conclusion, antiphospholipid syndrome and MS can be difficult to distinguish form each other. A careful medical history, a previous history of thrombosis and/or fetal loss, an abnormal localization of the lesions in MRI, demonstration of anti-phospholipid antibody positivity in blood tests performed at least 12 weeks apart, and the response to anticoagulant therapy might be helpful in the differential diagnosis. $\mathrm{n}$ addition, in oligoclonal band negativity, other vascular and inflammatory diseases other than MS should be considered and differential diagnosis should be made.

\section{Acknowledgements}

We thank the patient for granting us permission to publish this information. 


\section{REFERENCES}

1. Myakis S, Lockshin MD, Atsumi T, et al. International consensus statement on an update of the classification criteria for definite antiphospholipid syndrome (APS). J Thromb Haemost. 2006;4:295-306.

2. Laura Durcan and Michelle Petri. Epidemiology of the Antiphospholipid Syndrome Chapter 2. Handbook of Systemic Autoimmune Diseases. 2017;12:17-30.

3. Yoav Arnson, Yehuda Shoenfeld, Eisen Alon and Howard Amita. Antiphosholipid syndrome as neurological disease. Semin Arthritis Rheum. 2010; 40:97-108.

4. Andrew J, Solomon, Brain G. Weinshenker. Misdiagnosis of multiple sclerosis: Frequency, Causes, Effects, and Prevention. Curr. Neurol neurosci Rep. 2013; 13:403.

5. Cervera R, Piette JC, Front J, et al. Antiphospkolipid syndrome:clinical and immunologic manifestations and patterns of disease expression in a cohort of 1.000 patients. Arthritis rheum. 2002;46:1019-27.

6. Sanna G, Bertolaccini ML, Cuadrado MJ, et al. Central nervous system involvement in the antiphospholipid (Hughes) syndrome. Rheumatology. 2003;42:200-13.

7. Lockshin M, Tenedios F, Petri M, et al. Cardiac disease in the antiphospholipid syndrome:recommendations for treatment. Committee consensus report. Lupus. 2003;12:518-23.

8. Guillermo RI, Crowther M, Branch W, et al. Anti-phospholipid syndrome. Lancet. 2010;376:1498-1509.

9. Hughes GR. Thrombosis,abortion,cerebral disease, and the lupus anticoagulant. $\mathrm{Br}$ Med $J$ (Clin Res Ed). 1983; 287: 1088-89.

10. Sanna G, D'Cruz D,Cuadrado MJ. Cerebral manifestations in the antiphospholipid (Hughes) syndrome. Rheum Dis Clin North Am. 2006; 32: 465-90.

11. Yelnik CM, Kozora E, Appenzeller S. Nonstroke central neurologic manifestations in antiphospholipid syndrome. Curr Rheumatol Rep. 2016; 18:

12. Rodrigues CEM, Carvalho JF, Shoenfeld Y. Neurological manifestations of antiphospholipid syndrome. Eur J Clin Invest. 2010; 40 350-59.

13. Gris JC, Nobile B, Bouvier S. Neuropsychiatric presentations of antiphospholipid antibodies. Thromb Res. 2015; 135 (Suppl 1): S56-S59.

14. Fernandez-Fernandez FJ,Rivera-Gallego A,de la Fuente-Aguado J, et al. Antiphospholipid syndrome mimicking multiple sclerosis in two patients. Eur J Intern Med. 2006; 17: 500-502.

15. Cuadrado MJ, Khamashta MA, Ballesteros A, et al. Can neurologic manifestations of Hughes (antiphospholipid) syndrome be distinguished from multiple sclerosis? Analysis of 27 patients and review of the literature. Medicine (Baltimore). 2000; 79: 57-68.

16. Zhu DS, Fu J, Zhang Y, Li SX, Zhang GX, Guan YT, Dong Q. Neurological antiphospholipid syndrome: Clinical, neuroimaging, and pathological characteristics. J Neurol Sci. 2014;346:138-44.

17. Keiserman B, da Silva LF, Keiserman MW, et al. Lupoid sclerosis. Rheumatol Int. 2010;30:431-4.

18. Heinzlef $\mathrm{O}$, Weill $\mathrm{B}$, Johanet $\mathrm{C}$, et al. Anticardiolipin antibodies in patients with multiple sclerosis do not represent a subgroup of patients according to clinical, familial, and biological characteristics. J Neurol Neurosurg Psychiatry. 2002; 72: 647-49.

19. Liedorp M, Sanchez E, van Hoogstraten IMW, et al. No evidence of misdiagnosis in patients with multiple sclerosis and repeated positive anticardio- lipin antibody testing based on magnetic resonance imaging and long term follow-up. J Neurol Neurosurg Psychiatry. 2007; 78: 1146-48.

20. Bidot CJ, Horstman LL, Jy W, et al. Clinical and neuroimaging correlates of antiphospholipid antibodies in multiple sclerosis: A preliminary study. BMC Neurol. 2007; 7: 36.

21. Szmyrka-Kaczmarek M, Pokryszko-Dragan A, Pawlik B, et al. Antinuclear and antiphospholipid antibodies in patients with multiple sclerosis. Lupus. 2012; 21: 412-20.

22. Karussis D, Leker RR, Ashkenazi A, et al. A subgroup of multiple sclerosis patients with anticardiolipin antibodies and unusual clinical manifestations: Do they represent a new nosological entity? Ann Neurol. 1998; 44: 629-34.

23. Baraczka K, Lakos G, Sipka S. Immunoserological changes in the cerebrospinal fluid and serum in systemic lupus erythematosus patients with demyelinating syndrome and multiple sclerosis. Acta Neurol Scand. 2002; 105: 378-83.

24. Roussel V, Yi F, Jauberteau MO, et al. Prevalence and clinical significance of antiphospholipid antibodies in multiple sclerosis: A study of 89 patients. J Autoimmun. 2000; 14: $259-65$.

25. Garg N, Zivadinov R, Ramanathan M, et al. Clinical and MRI correlates of autoreactive antibodies in multiple sclerosis patients. $J$ Neuroimmunol. 2007; 187: 159-65.

26. Siva A. Common Clinical and Imaging Conditions Misdiagnosed as Multiple Sclerosis: A Current Approach to the Differential Diagnosis of Multiple Sclerosis. Neurol Clin. 2018 Feb;36:69-117.

27. Thompson AJ et al. Diagnosis of multiple sclerosis: 2017 revisions of the Mc Donald criteria. The Lancet Neurology. Feb 2018 ; Vol: 17, Issue 2: 162-173. 
28. Maria J Cuadrado, Munther A. Khamashta, Angel Ballesteros, et al. Can Neurologic manifestations of Hughes (Antiphospholipid) syndrome be distinguished from multiple sclerosis? Analysis of 27 patients and review of the literatüre. Medicine. 2000;1:57-68.

๑Copyright 2022 by Osmangazi Tıp Dergisi - Available online at tip.ogu.edu.tr @Telif Hakkı 2022 ESOGÜ Tıp Fakültesi - Makale metnine dergipark.org.tr/otd web sayfasından ulaşılabilir. 